\title{
Influencing Factors of the Export of Romanian Bee Products
}

\author{
Anca A. POPOVICI*1), Liviu Al. MĂRGHITAŞ ${ }^{1)}$, Daniel S. DEZMIREAN ${ }^{1)}$, Marioara ILEA ${ }^{2)}$ \\ ${ }^{1)}$ Faculty of Animal Science and Biotechnologies, University of Agricultural Sciences and Veterinary \\ Medicine, 3-5 Mănăştur Street, 400372 Cluj-Napoca, Romania \\ ${ }^{2)}$ Faculty of Horticulture, University of Agricultural Sciences and Veterinary Medicine, 3-5 Mănăştur \\ Street, 400372 Cluj-Napoca, Romania \\ *Corresponding author, email: anca.popovici@usamvcluj.ro
}

Bulletin UASVM Animal Science and Biotechnologies 71(2) / 2014,

Print ISSN 1843-5262; Electronic ISSN 1843-536X

DOI: $10.15835 /$ buasvmcn-asb:10342

\begin{abstract}
Current global policies are encouraging activities that determine the sustainable development of rural areas and the achievement of safe and high quality agri-food products. In this context, the present research aims to study the factors that influence the export of bee products which are consistent with the present tendency of consumers to purchase products that confer health benefits. The export of bee products is a process through which beekeepers seek opportunities for which there is demand in foreign markets and assume the risk of entering new markets in order to meet this demand. Following a survey conducted on a sample of 420 beekeepers from the North West Region of Romania, the results of the present research prove that the decision to export bee products is influenced by the following factors: the intention of setting up a firm, farm modernization, product diversification, collaboration, belonging to a group of producers, farm type and farm size. In addition, the paper shows that exports represent a strategy for the revitalization and transformation of the beekeeping sector as they imply finding market opportunities and promoting various and high quality bee products. The findings of the present study can assist beekeepers in their endeavor to formulate export strategies and succeed in international markets.
\end{abstract}

Keywords: export, bee products, entrepreneurship, farm modernization, product diversification, producer groups

\section{INTRODUCTION}

Bees play a vital role in maintaining the ecological balance and perpetuating many species of plants (Potts et al., 2010), being essential providers of the ecosystem service of pollination (Costanza et al., 1997). In Romania, beekeeping has developed in very favorable natural conditions in terms of the melliferous potential, climate, air and soil quality, thereby achieving a significant apicultural production (Pîrvuţoiu and Popescu, 2011). Due to the pollination of plants, bees provide the vegetable food for humans and animals, being an essential factor in assuring the sustainable biodiversity conservation, representing an element of equilibrium for the ecosystems (Brown and Paxton, 2009). Honey, pollen, propolis and beeswax are simultaneously food and medicine with high biological value for human consumption (Mărghitaș, 2005). Other bee products such as venom, royal jelly and apilarnil are also used to treat certain diseases. The food, pharmaceutical and cosmetic industries use bee products as raw material in the preparation of medicine, various recipes, creams etc. (Popovici and Mărghitaş, 2013). Hive products are very valuable and contribute to the increase of the income of those selling them (Saner et al., 2004; Urbisci, 2011). The economic importance of beekeeping is reflected in the employment of a part of the labor force in urban and rural areas in the care of bees, bee products processing, marketing, production of apicultural equipment etc. Bees also manifest social importance as apiculture enhances the national and international communication 
between people through exports.

Romania has the capacity to produce about 22.000 tones of honey yearly. In 2013, the total honey production was of 28.927 tones (RMARD, 2014). The average annual consumption of honey in Romania varies between 0.2 and $0.4 \mathrm{~kg}$ per capita (CBI Market Information Database, 2010). As Romania consumes only a third of the honey it produces, most of the Romanian honey (between 60 and $80 \%$ ) is exported. The countries to which Romania exports honey are: Germany, Italy, France, Austria, United Kingdom, Poland, Spain, Israel, Slovakia, The Netherlands, Japan (RMARD, 2014).

The export of bee products is achieved through the development of beekeeping farms, increased production and diversification, given the fact that, in order to export, large high quality quantities of honey are required. If beekeepers intend to export products, they have to choose their target markets and the most effective distribution channels to sell their products in the foreign country (Popovici and Mărghitaş, 2013).

Exports are extremely important for the economic development of a country (Couto et al., 2006, Girma et al., 2004; Lages and Montgomery, 2004). Hessels and van Stel (2011) investigate the relationship between new venture creation and economic growth, while taking into account new ventures' export orientation, and confirm the fact that export-driven new ventures contribute to the generation of knowledge spillovers, increased competition, and increased diversity, ultimately resulting in higher economic growth rates. Exports have a positive impact on the national amount of foreign exchange reserves and on national prosperity, contributing to the development of national industries, to the improvement of productivity, and to the creation of employment (Hessels and van Stel, 2011). According to Hessels and van Stel (2011), exporting new ventures develop specific skills (including human capital and innovative skills). Export activity may not only generate financial benefits for the firm, but can also be viewed as a process of learning and of accumulation of knowledge and technology (Blalock and Gertler 2004). However, exporting involves a higher risk (Lu and Beamish, 2001), is more expensive, requires more resources, and it is more difficult than selling to national markets. According to Ibeh (2004), with the right quality of decision makers, smaller firms could be properly led to procure and develop advantagecreating competencies that might enable them to overcome external internationalization barriers. Other studies indicate that there is a positive association between the entrepreneurial orientation and export performance (Okpara, 2009). Ibeh and Young (2001) suggest that exporting is an entrepreneurial act and can be defined as the process by which individuals either on their own or inside organizations pursue export market opportunities without regard to the resources which they currently control or environmental disincentives which they face (adapted from Stevenson et al., 1989). Exploitation of opportunities in entrepreneurial contexts represents the decision to act according to a particular opportunity, and the actions that are undertaken to use this opportunity. The exploitation process refers primarily to the acquisition of resources and their coordination (Davidsson, 2004). The export of bee products is considered an entrepreneurial strategy because the beekeeper has to carry out a complex market research in the respective foreign country in order to discover new opportunities, determine who will buy the products and where the customers are located. Therefore, new promotional materials appropriate for foreign customers should be developed (Popa et al., 2012). According to Zou and Cavusgil (2002), global performance can be maximized if business units develop an organization-wide market orientation, are committed to the global markets, nurture a kind of organization culture that is conducive to global strategy conception and implementation, create organizational capabilities and accumulate international experience.

According to Araya etal.(2007), modernization of beekeeping is achieved both through the modern equipment purchased and the beekeepers' own innovations. The latter are more affordable, more appropriate to local needs, being generally tested in the apiaries. Beekeepers generally transform a technology in order to respond to a specific need, often improving its efficiency. The acquisition of modern technology is at present a way to face the constraints imposed by globalization (Knight, 2000) and a prerequisite for improving the quality of products, which tend to be associated with firm performance (Zahra, 1996). 
Another strategy adopted by beekeeping firms is diversification. Theoretical models offer many different arguments about why firms diversify. One of the models is the synergy effects model which refers to cost advantages that emerge from the existence of joint production facilities, being cheaper to produce several goods jointly instead of producing each of them separately (Weiss and Briglauer, 2002). Therefore, a research undertaken in Canada (Urbisci, 2011) emphasizes the fact that the number of goods and services the apicultural enterprise offers explains variations in profits, implying that more diversified apiaries are likelier to generate higher revenue.

Regarding the role of collaboration for entrepreneurial export-oriented firms, Aldrich (1999) argues that personal networks of collaborators enhance entrepreneurial trust, providing advice, support and examples of good practice. Observing and interacting with other individuals, entrepreneurs acquire information and skills, learn how to find the most competent employees, to obtain financial support and identify potential buyers (Minniti, 2005). Social capital manifested through collaboration with various firms contributes to the spread of knowledge, having a positive effect on the performance of small and medium enterprises (Gibcus et al., 2009). Acquiring a rich social capital implies belonging to a network which ensures access to knowledge and various resources (Yli-Renko, 2001).

Entrepreneurship and innovation are considered to be key factors in the development of the agricultural sector (Phillipson et al., 2004). Exports play a very important part in triggering the entrepreneurial behavior of beekeepers due to the fact that, while exporting, beekeepers identify the opportunities that exist in foreign markets, confer added value to products and improve their marketing strategies. Moreover, in order to be successful entrepreneurs, beekeepers should collaborate with partners within the sector in order to have as much access to information as possible (Simoni and Labory, 2007). In this context, the present study fills a gap in the literature by identifying the factors that influence the export of bee products.

\section{MATERIALS AND METHODS}

The present paper emphasizes the influencing factors in the decision to export bee products, factors that can be integrated in a multicriteria decision support that can help beekeepers in the process of exporting bee products. The data within the present study were collected through a survey on a sample of 420 beekeepers from the North-West Region of Romania, members of the Romanian Beekeepers' Association, but not only, and beekeepers who applied for different European Union measures. The survey was conducted in 2011 and the data were analyzed using SPSS statistical program. The work tool used was the questionnaire, distributed during beekeepers' meetings, by post and on the Internet. The present study identifies what mainly triggers the decision to export bee products by testing the association between several variables and the export of bee products using Pearson $\chi^{2}$ (Chi square) test.

\section{RESULTS AND DISCUSSION}

Romania exports annually about $70 \%$ of the annual production of honey (RMARD, 2014). The following two figures (Fig. 1 and Fig. 2) present the quantity of honey (kg) exported by Romania from 2007 to November 2013 and its value in Euros. In 2009, there was an increase in the quantity of honey exported following the European Union measures supporting apiculture, the increase in the number of hives and the favorable weather conditions.

In 2010, the total European honey production was estimated at over 220000 tons. About 200 000 tons of honey were imported into the different countries of the community in 2010; while 90000 tons were exported from the countries. Germany imported and exported the largest quantities of honey in Europe in 2010 (respectively around 90000 tons and 20000 tons). The main honey distribution network was retail distribution (Chauzat et al., 2013).

Figure 3 presents the main countries to which Romania exported honey in 2012 and the quantities of honey exported. The high quantity of honey exported to Germany is due to the high per capita consumption of honey (1.3 kg/year) in this country (Schneider et al., 2007). Exact data on the production of pollen, royal jelly, queens and packages at national level is not available.

The purpose of the present paper is to study the factors that influence the export of bee products. The following factors are taken into consideration 


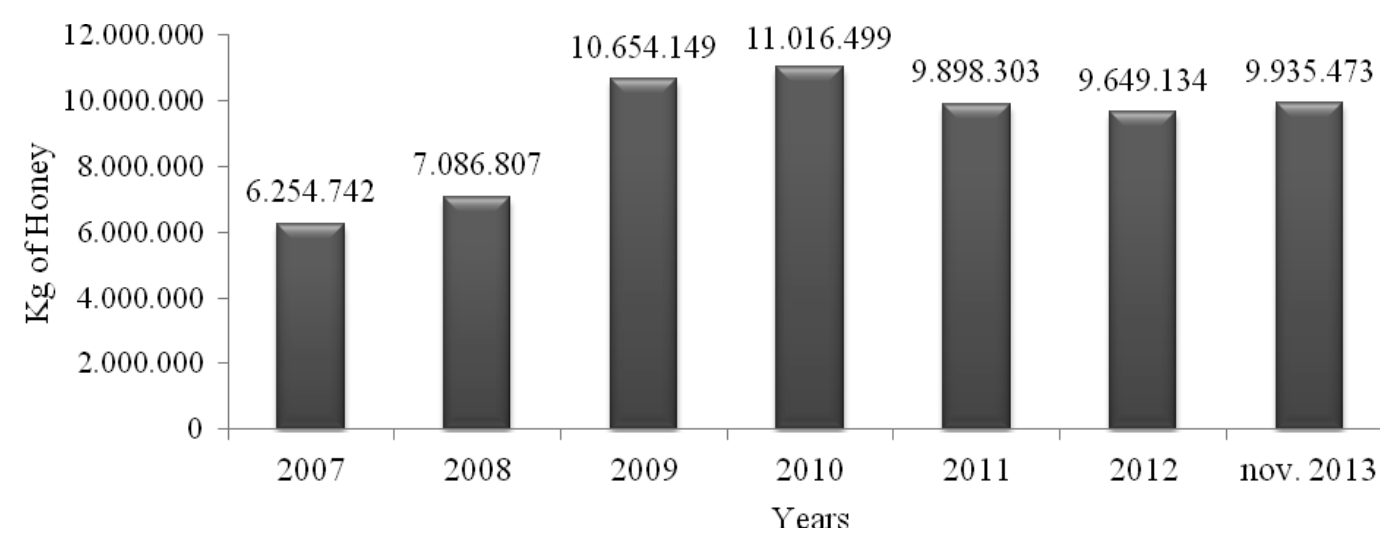

Fig. 1. Quantity of honey (kg) exported by Romania from 2007 to November 2013

Source: Own processing after data from the Romanian National Institute of Statistics, 2014

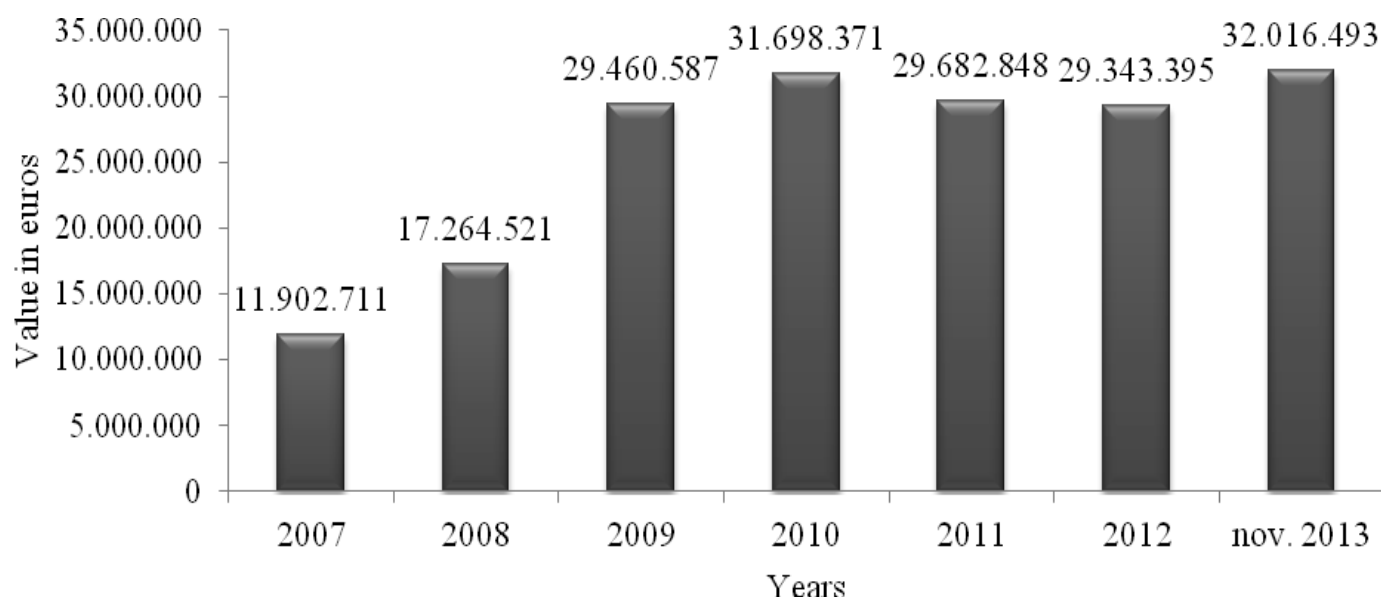

Fig. 2 Value in Euros of honey exported by Romania from 2007 to November 2013 Source: Own processing after data from the Romanian National Institute of Statistics, 2014

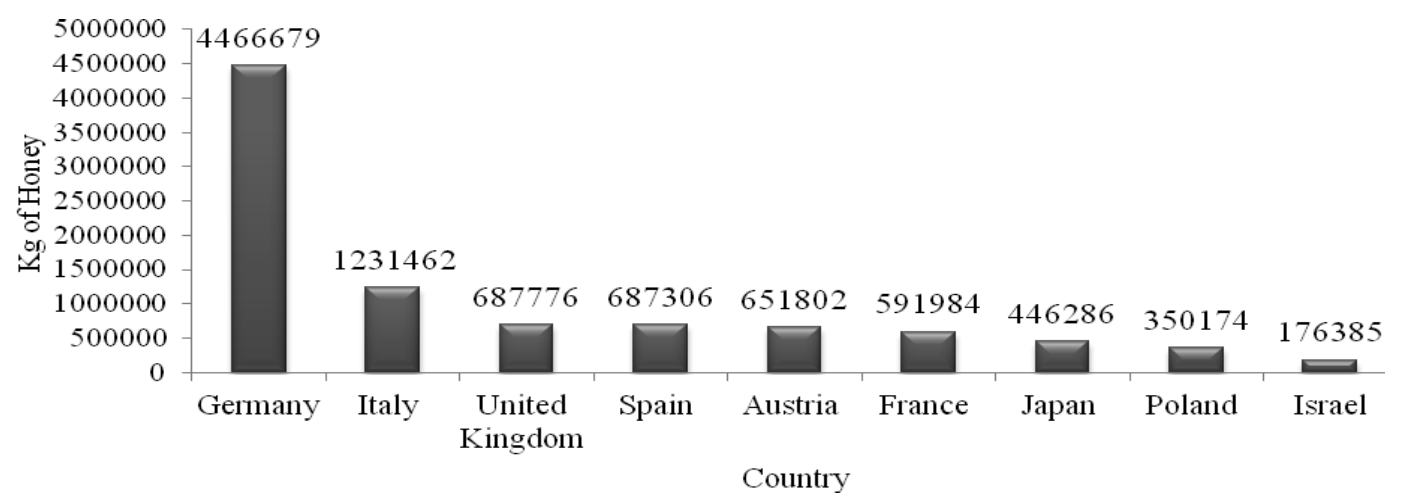

Fig. 3 The main countries to which Romania exported honey in 2012 and the quantity of honey; Source: Own processing after data from the Romanian Ministry of Agriculture and Rural Development, 2014

due to their importance in the scientific literature related to exports (Ibeh and Young, 2001; Popa et al., 2012): intention to set up a beekeeping firm, farm modernization, product diversification, collaboration, belonging to producer groups, farm size (number of colonies of bees) and the type of beekeeping farm (Tab. 1). The following table presents the frequencies of the variables being studied. According to the results of the present study, a percentage of $24.3 \%$ of the respondents export bee products and $75.7 \%$ do not export bee products. As it can be observed in the above table, 
$56.6 \%$ of the respondents that intend to set up a new venture in the following three years export bee products. Therefore, the proportion of those who intend to set up a firm is higher in the case of those who export bee products.

In order to reach a much higher level of performance it is absolutely necessary for Romanian beekeepers to purchase modern equipment. Modernization of the beekeeping farms and products obtained according to the principles of sustainability and food security require continuous search for new sources to generate a competitive advantage. This implies the ability to capitalize all the resources of the apiary and to combine them in an original way so as to create new sources of value. Accordingly, $98.0 \%$ of the beekeepers who modernize their beekeeping farms export bee products. As for product diversification, $33.0 \%$ of beekeepers that adopt this strategy export their products. As regards the products sold, $93.1 \%$ of beekeepers sell honey, $59.7 \%$ propolis, $49.4 \%$ pollen, $43.9 \%$ sell wax and $8.8 \%$ royal jelly.

In order to promote their products more easily and to be able to negotiate a better price, beekeepers set up producer groups. A total of eight respondents $(1.9 \%)$ are members of a producer group and $20.2 \%$ of the respondents plan to become members of a group of producers. $2.0 \%$ of beekeepers who belong to producer groups export their bee products and $34.0 \%$ who intend to become members of producer groups export bee

Tab. 1. Frequencies of variables studied

\begin{tabular}{|c|c|c|c|}
\hline \multirow{2}{*}{ Variable } & \multirow{2}{*}{ Category } & \multicolumn{2}{|c|}{ Export of bee products (\%) } \\
\hline & & Yes & No \\
\hline \multirow{2}{*}{$\begin{array}{l}\text { Intention to set up a } \\
\text { beekeeping firm }\end{array}$} & Yes & $56.6 \%$ & $30.6 \%$ \\
\hline & No & $43.4 \%$ & $69.4 \%$ \\
\hline \multirow{2}{*}{ Farm modernization } & Yes & $98.0 \%$ & $88.7 \%$ \\
\hline & No & $2.0 \%$ & $11.3 \%$ \\
\hline \multirow{2}{*}{ Product diversification } & Yes & $33.0 \%$ & $57.9 \%$ \\
\hline & No & $67.0 \%$ & $42.1 \%$ \\
\hline \multirow{5}{*}{ Collaboration } & I do not collaborate & $13.0 \%$ & $23.8 \%$ \\
\hline & Very rarely & $4.0 \%$ & $5.1 \%$ \\
\hline & Rarely & $24.0 \%$ & $27.7 \%$ \\
\hline & Often & $30.0 \%$ & $28.0 \%$ \\
\hline & Very often & $29.0 \%$ & $15.4 \%$ \\
\hline \multirow{3}{*}{$\begin{array}{l}\text { Belonging to producer } \\
\text { groups }\end{array}$} & Yes & $2.0 \%$ & $1.9 \%$ \\
\hline & $\begin{array}{l}\text { No, but I intend to become a } \\
\text { member }\end{array}$ & $34.0 \%$ & $16.4 \%$ \\
\hline & $\begin{array}{l}\text { No and I do not intend to } \\
\text { become a member }\end{array}$ & $64.0 \%$ & $81.7 \%$ \\
\hline \multirow{4}{*}{$\begin{array}{l}\text { Farm size (number of } \\
\text { colonies of bees) }\end{array}$} & maximum 50 colonies of bees & $28.0 \%$ & $52.4 \%$ \\
\hline & $51-100$ colonies of bees & $36.0 \%$ & $30.2 \%$ \\
\hline & $101-150$ colonies of bees & $16.0 \%$ & $9.3 \%$ \\
\hline & over 150 colonies of bees & $20.0 \%$ & $8.0 \%$ \\
\hline \multirow[t]{5}{*}{ Type of beekeeping farm } & Individual & $36.0 \%$ & $58.5 \%$ \\
\hline & Sole proprietorship & $45.0 \%$ & $32.2 \%$ \\
\hline & Individual enterprise & $10.0 \%$ & $5.8 \%$ \\
\hline & Family enterprise & $8.0 \%$ & $3.5 \%$ \\
\hline & Limited Liability Company & $1.0 \%$ & $.0 \%$ \\
\hline
\end{tabular}

Source: Own processing in SPSS 
products. Producer groups are also set up because they represent a means to facilitate the access to significant funding through different European programs.

In order to increase production and profit, beekeepers use several methods, namely: identifying the optimal size of the apiary, maintaining strong colonies, pest and disease management, use of modern beekeeping technologies etc. The survey shows that a share of $47.1 \%$ of beekeepers have up to 50 colonies of bees, which implies the need for the implementation of measures at the national level meant to support beekeepers towards increasing the number of bee colonies. In addition, for the export of bee products to be profitable, it must be based on beekeeping farms that comprise a large number of bee colonies, generally over 100 . Only $10.7 \%$ of the beekeeping farms have over 150 colonies of bees. $20.0 \%$ of the beekeepers that have over 150 colonies of bees export bee products. Analyzing the types of beekeeping farms, it can be noted that $54 \%$ of beekeepers are individuals, $34.5 \%$ are registered as sole proprietorship, $6.7 \%$ have an individual enterprise, $4.5 \%$ are family businesses, and only $0.2 \%$ have a company. $45.0 \%$ of beekeepers that are Sole proprietorship export bee products. In the case of the highlighted proportions, there are significant differences at 0.05 level.

The purpose of the present paper is to study the connection between the export of bee products and the intention to set up a beekeeping firm, farm modernization, product diversification, collaboration, belonging to producer groups, farm size and type of beekeeping farm using the $\chi^{2}$ test. The null hypothesis of the test is that there is no significant association between the export of bee products and the other variables. The obtained significance levels are less than 0.05, which demonstrates that there is a significant connection between the variables and the export of bee products, a fact confirmed by the $\chi^{2}$ test (Tab. 2).

Table 2 presents the main factors that influence the export of bee products. There is a significant connection between the variables listed in the table and the export of bee products. As shown in Table 2, innovation strategies (modernization and product diversification) influence the export of bee products. According to the scientific literature (Hitt et al., 1997), product diversification moderates the relationship between international di-
Tab. 2. Influencing factors of the export of bee products

\begin{tabular}{lccc}
\hline Variable & Pearson $\chi^{2}$ & $\mathrm{df}$ & Asymp. Sig \\
\hline $\begin{array}{l}\text { Intention to set up a } \\
\text { beekeeping firm }\end{array}$ & 21.648 & 1 & 0.000 \\
\hline Farm modernization & 7.910 & 1 & 0.005 \\
\hline Product diversification & 18.758 & 1 & 0.000 \\
\hline Collaboration & 12.288 & 4 & 0.015 \\
\hline $\begin{array}{l}\text { Belonging to producer } \\
\text { groups }\end{array}$ & 14.391 & 2 & 0.001 \\
\hline $\begin{array}{l}\text { Type of beekeeping } \\
\text { farm }\end{array}$ & 19.116 & 4 & 0.001 \\
\hline $\begin{array}{l}\text { Size of the beekeeping } \\
\text { farm }\end{array}$ & 23.469 & 3 & 0.000 \\
\hline Source: Own processing in SPS & & & \\
\hline
\end{tabular}

Source: Own processing in SPSS

versification and performance. International diversification is positively related to performance in highly product-diversified firms (Hitt et al., 1997). Product diversification and new product creation represent a way to increase company interests. For the strategy of creating new products to be successful, the company should identify a need and create products that provide value to consumers (Borza et al., 2009).

Regarding innovations that are implemented in the existing firms, Covin and Kuratko (2008) highlight the fact that they are adopted in order to gain a competitive advantage. Innovations can bring forth fundamental changes in the past strategies of the company, products, markets and organizational structures, processes, capabilities and business models. Such innovations may be the basis that fundamentally distinguishes the firm from its rivals in the field (Covin and Kuratko, 2008).

The other factors that induce the export of bee products are: the intention to start a beekeeping firm, collaboration, belonging to producer groups, the type of beekeeping farm and farm size. In order to facilitate the export of bee products, enhanced cooperation between beekeeping farms is required. Being part of a network of friends, advisors and partners promotes the discovery of new opportunities in the beekeeping sector. Working with different beekeeping firms enables beekeepers to have access to a set of valuable information that can be used to gain competitive advantage through a strategic decision-making process. The beekeeping sector capital is formed 
through a variety of relationships, including those with customers, suppliers, distributors and strategic partners. Generally, the most innovative beekeepers are part of a strong social network with access to valuable information and financial aid. Observing and interacting with other individuals, entrepreneurs acquire information and skills, learn how to find the most competent employees, gain financial support and identify potential buyers (Minniti, 2005).

Resource mobilization and discovery of opportunities are the most important factors involved in the process of exploring foreign markets. The export of bee products is supported by beekeepers' actions to promote bee products and by the efficient selection of possible foreign distribution channels.

\section{CONCLUSION}

Various aspects of the external environment specific to rural areas represent challenges for small beekeeping farms. Small local markets and remoteness from major national and international markets are some of the disadvantages faced by small-scale beekeeping farms. Due to the low level of business opportunities in rural areas, beekeeping farms must set up producer groups in order to successfully export their bee products.

The results of the present study emphasize the fact that there is a significant connection between the export of bee products and the following factors: intention to set up a beekeeping firm, modernization of the farm, product diversification, collaboration, belonging to producer groups, type of beekeeping farm and farm size. The findings of the current study are consistent with those that state that there is a positive association between the entrepreneurial orientation and the export performance (Okpara, 2009). The decision to export bee products involves product diversification and bringing new products to foreign markets. Beekeepers who intend to enter new markets and export their products should undertake an entrepreneurial behavior and diversify their offer of products, findings which complement the scientific literature which states that product adaptation strategy is positively associated with export performance (Calantone et al., 2006) and that the implementation of a welldesigned export marketing strategy can determine export success (Leonidou et al., 2002).
Therefore, the findings of the present study provide new insights regarding the factors that influence and support beekeepers' decision to export bee products and can be extended at an European level. Taking into consideration the high proportion of non-professional beekeepers at European level and the small mean number of colonies per beekeeper (Chauzat et al., 2013), social capital represents a valuable resource for beekeepers who export bee products because it facilitates the flow of information, it promotes the recognition of opportunities and results in an increase of the availability of resources. Consequently, the export of bee products involves the transformation of small-scale beekeeping farms into viable market-oriented firms, able to provide a wide range of high quality bee products.

Acknowledgments. This paper was published under the frame of European Social Fund, Human Resources Development Operational Programme 2007-2013, projectno. POSDRU/159/1.5/S/132765.

\section{REFERENCES}

1. Aldrich, H. (1999). Organizations Evolving. Sage. London: 20-31.

2. Araya, H., G. M. Yohannes, A. Gebre Amlak and A. WatersBayer (2007). Participatory research that builds on local innovation in beekeeping to escape poverty. Rural Development News: 29-33.

3. Blalock, G. and P. J. Gertler (2004). Learning from exporting revisited in a less developed setting. Journal of Development Economics. 75(2): 397-416.

4. Borza, A., C. Mitra, O. Bordean, A. Mureşan and R. Supuran (2009). Entrepreneurship. The Management of small and medium-sized companies. Edit. Risoprint. Cluj-Napoca: 42-53.

5. Brown, M.J.F. and R.J. Paxton (2009). The conservation of bees: a global perspective. Apidologie. 40: 410-416.

6. Calantone, R. J., K. Daekwan, J.B. Schmidt and S.T. Cavusgil (2006). The influence of internal and external firm factors on international product adaptation strategy and export performance: A three-country comparison. Journal of Business Research. 59: 176 - 185.

7. CBI Market Information Database (2010), www.cbi.eu

8. Chauzat, M. P., L. Cauquil, L. Roy, S. Franco, P. Hendrikx and M. Ribičre-Chabert (2013). Demographics of the European Apicultural Industry. PloS ONE. 8(11): e79018.

9. Costanza, R., R. d'Arge, R. de Groot, S. Farber, M. Grasso, B. Hannon, K. Limburg, S. Naeem, R.V. O'Neill, J. Paruelo, R.G. Raskin, P. Sutton, M. van den Belt (1997). The value of the World's ecosystem services and natural capital. Nature 387: 253-259. 
10. Couto, J.P.A., M.T.B Tiago, J.C. Vieira and M.A. Fortuna (2006). Contextual and operational determinants of export performance of companies in Europe. The Business Review. 5(1): 145-154.

11. Covin,J.G. and D.F. Kuratko (2008). The concept of corporate entrepreneurship. In: V. Narayanan \& G. O'Connor (eds.), The Blackwell encyclopedia of technology and innovation management. Oxford. UK. Blackwell Publishers: 207-212.

12. Davidsson, P. (2004). Researching Entrepreneurship. Springer. Boston: 35-41.

13. Gibcus, P., P.A.M. Vermeulen and J.P.J. de Jong (2009) Strategic decision-making in small firms: a taxonomy of small business owners. International Journal of Entrepreneurship and Small Business. 7(1): 74-91.

14. Girma, S., D. Greenaway and R. Kneller (2004). Does exporting increase productivity? A microeconomic analysis of matched firms. Review of International Economics. 12 (5): 855-866.

15. Hessels, J. and A. van Stel (2011). Entrepreneurship, export orientation, and economic growth. Small Business Economics. 37: 255-268.

16. Hitt, M. A., R. E. Hoskisson and H. Kim (1997) International diversification: Effects on innovation and firm performance in product-diversified firms, Academy of Management Journal. 40: 767-798.

17. Ibeh, K.I. (2004). Furthering export participation in less performing developing countries: The effects of entrepreneurial orientation and managerial capacity factors. International Journal of Social Economics. 31(1/2): 94-110.

18. Ibeh, K.I. and S. Young (2001). Exporting as an entrepreneurial act - An empirical study of Nigerian firms. European Journal of Marketing. 35(5/6): 566-586.

19. Knight, G. (2000). Entrepreneurship and Marketing Strategy: The SME Under Globalization. Journal of International Marketing. 8(2): 12-32.

20. Lages, L. F. and D. B. Montgomery (2004). Export performance as an antecedent of export commitment and marketing strategy adaptation. Evidence from small and medium-sized exporters. European Journal of Marketing. 38(9-10): 1186-1214.

21. Leonidou, L.C., C.S. Katsikeas and S. Samiee (2002). Marketing strategy determinants of export performance: a meta-analysis. Journal of Business Research. 55(1):51 67.

22. Lu, J. W. and P.W. Beamish (2001). The internationalization and performance of SMEs. Strategic Management Journal. 22(6-7): 565-586.

23. Mărghitaş, L. Al. (2005). Bees and their products. Ceres Bucharest: 280-287.

24. Minniti, M. (2005). Entrepreneurship and Network Externalities. Journal of Economic Behavior and Organizations. 57(1): 1-27.

25. Okpara, J.O. (2009). Entrepreneurial Orientation and Export Performance: Evidence from an Emergent Economy. International Review of Business Research Papers. 5(6): 195-211.
26. Phillipson, J., M. Gorton, M. Raley and A. Moxey (2004). Treating farms as firms? The evolution of farm business support from productionist to entrepreneurial models. Environment and Planning C: Government and Policy. 22: 31-54.

27. Pîrvuţoiu I. and A. Popescu (2011). Analysis of Romania's Honey Market. Scientific Papers: Animal Science and Biotechnologies. 44(2): 500-503.

28. Popa, A., L. Mărghitaş, and C. B. Pocol (2012). Export of Honey as an Entrepreneurial Strategy in the Beekeeping Sector, Bulletin USAMV Serie Horticulture. 69 (2): 392393.

29. Popovici, A. and L. Mărghitaş (2013). Entrepreneurship in the beekeeping sector. Edit. Academic Pres. Cluj-Napoca: 1-20.

30. Potts, S.G., J.C. Biesmeijer, C. Kremen, P. Neumann, 0. Schweiger and W.E. Kunin (2010). Global pollinator declines: trends, impacts and drivers. Trends Ecol. Evol. 25: 345-353.

31. Romanian Ministry of Agriculture and Rural Development (2014). www.madr.ro.

32. Romanian National Institute of Statistics (2014). www. insse.ro.

33. Saner, G., S. Engindeniz, B. Tolon and F. Cukur (2004). The economic analysis of beekeeping enterprise in sustainable development: a case study of Turkey. APIACTA. 38: 342351.

34. Schneider, K., K. Forchmann, K. Friedrichs, E.-M. Haas, M. Interthal, K. Jänicke, T. Kühn et al. (2007). Honey consumption in Germany. Factors of influence and effects in their interlinkage. Apidologie. 38 (5): 497.

35. Simoni, C. and S. Labory (2007). The Influence of Social Capital on Entrepreneurial Behavior In: Entrepreneurship, The Engine of Growth, volume 1, Edited by Maria Minniti et al., Praeger Publishers: 101-118.

36. Stevenson, H.H., M.J. Roberts and D.E. Grousbeck (1989). New Business Ventures and the Entrepreneur, Irwin. Homewood, IL.

37. Urbisci, L. (2011). The economic effects of size and enterprise diversity on apiary profits in Canada, The Department of Food, Agricultural and Resource Economics of The University of Guelph: 55-60.

38. Weiss, C. and W. Briglauer (2002). Determinants and Dynamics of Farm Diversification, Paper prepared for presentation at the $10^{\text {th }}$ EAAE Congress, Zaragoza, Spain. August: 28-31.

39. Yli-Renko, H., E. Autio and H. J. Sapienza (2001). Social capital, knowledge acquisition, and knowledge exploitation in young technology-based firms. Strategic Management Journal 22: 587-613.

40. Zahra, S. (1996). Technology Strategy and Financial Performance: Examining the Moderating Role of the Firm's Competitive Environment, Journal of Business Venturing. 11(3): 189-219.

41. Zou, S. and S.T. Cavusgil, (1996). Global strategy: a review and an integrated conceptual framework. European Journal of Marketing. 30(1): 52 -69. 